\title{
PENGARUH KETERSEDIAAN BAHAN BAKU TERHADAP PENDAPATAN PENGRAJIN GENTENG DI DESA GEDUNG REJO BK IX BELITANG OKU TIMUR
}

\author{
Ratnawati ${ }^{1}$, Miftakhur Rohmah ${ }^{2}$ Rafika Rahmadani ${ }^{3}$ \\ ${ }^{1,2,3}$ Program Studi Pendidkan Ekonomi STKIP Nurul Huda \\ *E-mail: : ratnaawatii67@gmail.com
}

\begin{abstract}
Abstrak: Penelitian berjudul "Pengaruh Ketersediaan Bahan Baku Terhadap Pendapatan Pengrajin Genteng di Desa Gedung Rejo BK IX Belitang OKU TIMUR". Penelitian ini bertujuan untuk mengetahui pengaruh ketersediaan bahan baku terhadap pendapatan pengrajin genteng di Desa Gedung Rejo BK IX Belitang OKU Timur. Penelitian ini merupakan penelitian kuantitatif deskriptif. Adapun populasi dalam penelitian ini adalah seluruh pengrajin genteng di desa Gedung Rejo BK IX kecamatan Belitang kabupaten OKU Timur. Teknik pengambilan sampel pada penelitian ini adalah Cluster random sampling yang terdiri dari 30 pengrajin genteng desa Gedung Rejo BK IX kecamatan Belitang kabupaten OKU Timur. Teknik pengumpulan data dalam penelitian ini menggunakan observasi dan dokumentasi. Teknik analisis data yang digunakan adalah analisis regresi ganda. Hasil analisis pengolahan data penelitian menunjukkan bahwa pembelajaran berbasis daring termasuk dalam kategori sedang dan mencapai presentase sebesar $71,43 \%$ sedangkan untuk minat belajar peserta didik termasuk
\end{abstract}

Kata Kunci: Ketersediaan Bahan Baku; Pendapatan Pengrajin Genteng

\section{PENDAHULUAN}

Pembangunan nasional meliputi semua aspek kehidupan, salah satunya dibidang ekonomi. Pembangunan nasional merupakan suatu usaha yang sadar dan terarah dari suatu bangsa untuk meningkatkan kesejahteraan rakyatnya melalui pemanfaatkan sumber daya yang ada, baik dari dalam maupun dari luar daerah. Pembangunan dibidang ekonomi dilaksanakan untuk mewujudkan pemerataan hasilhasil pembangunan. Salah satu sektor dibidang ekonomi tersebut adalah industri kecil. Pembangunan pada sektor industri kecil diarahkan agar mampu berkembang secara mandiri dan meningkatkan pendapatan masyarakat.Salah satu tantangan yang dihadapi industri nasional saat ini adalah daya saing yang rendah dipasar internasional. Peran pemerintah terhadap industri kecil adalah bagaimana menumbuhkan iklim usaha dengan menerapkan peraturan perundangan dan kebijakan yang meliputi aspek pendanaan, sarana prasarana, informasi usaha, kemitraan, perizinan usaha, kesempatan berusaha, dan promosi dagang. 


\section{Pengaruh Ketersediaan Bahan Baku Terhadap Pendapatan Pengrajin Genteng Di Desa Gedung Rejo Bk Ix Belitang Oku Timur}

Belitang merupakan salah satu Kecamatan di Kabupaten OKU Timur dengan keragaman budaya, dan suku yang menarik. Akan tetapi Sektor industri genteng merupakan sektor yang mendominasi perekonomian desa Gedung Rejo BK IX Kecamatan Belitang. Di dalam pembangunan sektor industri bukan hanya membangun pabrik dan memasarkan hasil produksinya namun membangun sistem untuk berkembang secara mandiri pada struktur ekonomi masyarakat setempat.

Belitang merupakan Kecamatan yang sebagian besar masyarakatnya bekerja sebagai petani. Saat ini pertanian merupakan sektor dominan di kecamatan Belitang, sementara sektor industri kebanyakan didominasi industri kecil. Sektor industri kecil di desa Gedung Rejo Kecamatan Belitang mempunyai potensi untuk dikembangkan mengingat sumber dayaalam lokal dan kreativitas masyarakat pada bidang seni ataupun bidang kerajinan cukup memberikan kontribusi pada peningkatan kesejahteraan.

Perkembangan sektor industri pengrajin genteng dan industri lainnya di Kecamatan Belitang tidak terlepas dari peran masing-masing kabupaten atau kota. Pembangunan sebuah wilayah atau kabupaten tidak terlepas dari pertumbuhan ekonomi wilayah tersebut, potensi perekonomian suatu wilayah dapat diketahuidari tingkat pertumbuhan ekonomi. Salah satunya adalah Kecamatan Belitang yang merupakan salah satu kecamatan yang terkenal dengan berbagai industri genteng rumahannya di Kabupaten OKU Timur.

Sektor industri diharapkan lebih berperan dalam usaha menyeimbangkan struktur ekonomi daerah dari agraris menjadi industri. Untuk penyeimbangan industri di daerah Belitang merupakan suatu hal yang tidak dapat ditawar-tawar lagi guna memecahkan masalah kesempatan kerja dan kesempatan berusaha serta memperbesar nilai tambah dalam rangka meningkatkan kesejahteraan rakyat.

Namun demikian industri kecil dalam perkembangannya masih menghadapi berbagai persoalan yang perlu mendapat perhatian dari berbagai pihak antara lain sulitnya dalam ketersediaan mendapatkan bahan baku. Di desaGedung Rejo Kecamatan Belitang sediri UKM (Usaha Kecil Menengah) memiliki perkembangan usaha yang baik. Industri kerajinan genteng diKabupaten OKU Timur merupakan salah satu sentra indutri genteng. Tepatnya di desa Gedung Rejo Kecamatan Belitang. Desa Gedung Rejo merupakan salah satu desa yang banyak penduduknya sebagai pengrajin genteng dengan kualitastinggi. Masyarakat sekitar memanfaatkan 
tanah liat sebagaibahanbaku pembuatan genteng. Industri ini merupakan jenis usaha industri yang termasuk dalam katagori usaha industri pengolahan, yang mengelolah tanah liat sebagai bahan baku menjadi genteng. Masyarakat Gedung Rejo telah mampu memanfaatkan sumber daya alam yang ada disekitarnya untuk dijadikan sebagai sumbe penghasilan.

Industri di pedesaan mempunyai arti penting dalam usaha mengurangi tingkat kemiskinan di pedesaan atau dengan kata lain diharapkan dapat meningkatkan pendapatan serta penyerapan tenaga kerja masyarakat pedesaan. Meningkatnya jumlah penduduk akan diikuti dengan pertambahan jumlah tenaga kerja. Salah satu kegiatan yang banyak menyerap tenaga kerja adalah sektorindustri, yang sampai sekarang masih dapat bertahan bahkan cenderung semakin mengalami peningkatan.

Secara geografi ekonomi, sebagai daerah kerajinan Desa Gedung Rejo, Kecamatan Belitang, Kabupaten OKU Timur semestinya memiliki dukungan komponen diantaranya ketersediaan bahanbaku. Industri kerajinan genteng di Desa Gedung Rejo Kecamatan Belitang, Kabupaten OKU Timur sebagai salah satu unsur pokok dalam mengembangkan suatu industri kerajinan ini yang belum dapat terpenuhi sampai saat ini, karena masyarakat muda memilih untuk beralih profesi dan melakukan mobilitas ke kota sehingga mempengaruhi keberlangsungan industri genteng di Desa Gedung Rejo.

Tersedianya bahan baku dalam jumlah yang cukup, berkesinambungan dan harga yang dapat dijangkau akan memperlancar produksi yang pada akhirnya akan meningkatkan produksi serta meningkatkan jumlah pendapatan usaha yang diperoleh. Pendapatan usaha pada dasarnya merupakan ukuran berhasil tidaknya perusahaan dalam menjalankan usahanya.Perkembangan industri kerajinan genteng di Desa Gedung Rejo Kecamatan Belitang, Kabupaten OKU Timur menghadapi banyak kendala yang hampir sama dengan yang dialami industri rumah tangga, kecil dan menengah lainnya dimana masalah utamanya adalah kurangnya ketersediaan bahan baku. Karena sulitnya mendapatkan tanah liat, dan harga tanah liat cukup mahal.

Pada umunya pendapatan pekerja di pedesaan relatif kecil daripada jumlah tenaga kerja yang besar. Namun kecilnya pendapatan tersebut tidak hanya disebabkan oleh penawaran yang lebih dari permintaan, tetapi juga faktor intern 


\section{Pengaruh Ketersediaan Bahan Baku Terhadap Pendapatan Pengrajin Genteng Di Desa Gedung Rejo Bk Ix Belitang Oku Timur}

pada diri pekerja tersebut, antara lain adanya produktivitas mereka rendah dan curahan waktu untuk bekerja hanya sedikit. Keberlangsungan produksi industri kerajinan genteng dapat dipusatkan di Desa Gedung Rejo Kecamatan Belitang KabupatenOKU Timur karena home industri kerajinan genteng paling banyak berada di Desa Gedung Rejo Kecamatan Belitang. Berdasarkan uraian tersebut peneliti melaksanakan kajian penelitian dengan judul "Pengaruh Ketersediaan Bahan Baku Terhadap Pendapatan Pengrajin Genteng Di Desa Gedung Rejo BK IX Belitang OKU Timur".

\section{METODE}

Penelitian ini merupakan penelitian kuantitatif deskriptif (Arikunto:2013). Tujuan penelitian lebih diarahkan untuk menunjukkan hubungan antar variabel, memverifikasi teori, melakukan prediksi, dan generalisasi. Jenis penelitian yang akan digunakam dalam penelitian ini adalah asosiatif. Penelitian asosiatif merupakan penelitian yang bertujuan untuk mengetahui pengaruh ataupun hubungan antara dua variabel atau lebih (Yulianti: 2015) . Adapun populasi dalam penelitian ini adalah seluruh pengrajin genteng di desa Gedung Rejo BK IX kecamatan Belitang kabupaten OKU Timur.

Tabel 3.1

Populasi Pengrajin Genteng di Desa Gedung Rejo BK IX Kecamatan Belitang Kabupaten OKU Timur

\begin{tabular}{|ccc|}
\hline No & Dusun & Jumlah Populasi \\
\hline 1 & I & 27 \\
\hline 2 & II & 31 \\
\hline 3 & III & 26 \\
\hline 4 & IV & 35 \\
\hline 5 & V & 29 \\
\hline 6 & VI & 25 \\
\hline 7 & VII & 28 \\
\hline 8 & VIII & 33 \\
\hline 9 & IX & 30 \\
\hline 10 & X & 24 \\
\hline 11 & XI & 30 \\
\hline
\end{tabular}

Sumber : Hasil Penelitian Tahun 2020

Teknik pengambilan sampel dalam penelitian ini adalah cluster sampling atau area sampling. Sugiyono (2016:126) mengatakan teknik cluster sampling adalah teknik pengambilan sampel dengan cara menentukan daerah atau bagian. 
Teknik ini dilaksanakan dengan menggunakan stratified random sampling. Peneliti mengambil sampel dari dusun IX yang terdiri dari 30 pengrajin genteng desa Gedung Rejo BK IX kecamatan Belitang kabupaten OKU Timur.

Tabel 3.2

Sampel Pengrajin Genteng di Desa Gedung Rejo BK IX Kecamatan Belitang Kabupaten OKU Timur

\begin{tabular}{|ccc|}
\hline No & Dusun & Jumlah Sampel \\
\hline 1 & IX & 30 \\
\hline
\end{tabular}

\section{Teknik Analisis Data}

Berdasarkan jenis data yang telah diperoleh maka teknik pengelolaan data atau analisis data yang dipergunakan adalah data kuantitatif, yaitu dengan mengelolah kemudian disajikan dalam bentuk tabel untuk mempersentasekan hasil perolehan data tersebut kemudian dianalisis. Tujuan analisis data dalam penelitian kuantitatif adalah mencari makna di balik data, melalui pengakuan subyek pelakunya pengujian analisis data menggunakan alat bantu SPSS.25. Analisis data yang digunakan dalam penelitian ini adalah: Uji Deskriptif

Sugiyono(2012:148) menyatakan bahwa "Statistik deskriptif adalah statistik yang digunakan untuk menganalisa data dengan cara mendeskripsikan atau menggambarkan data yang telah terkumpul sebagaimana adanya tanpa bermaksud membuat kesimpulan yang berlaku untuk umum atau generalisasi".

\section{Pengecekan Keabsahan Data}

1. Uji Normalitas

Uji normalitas data adalah sebuah pengujian yang dilakukan untuk mengecek apakah data yang sedang diteliti berasal dari populasi yang mempunyai sebaran normal. Uji normalitas data penting untuk dilakukan karena perhitungan statistik parametrik mempunyai asumsi yang mengatakan bahwa data yang diteliti harus berdistribusi normal.

2. Uji homogenitas 


\section{Pengaruh Ketersediaan Bahan Baku Terhadap Pendapatan Pengrajin Genteng Di Desa Gedung Rejo Bk Ix Belitang Oku Timur}

Uji homogenitas data digunakan untuk menguji apakah kedua data tersebut homogen Arikunto, (2014;109). Jika kedua data varians sama besarnya, maka uji homogenitas tidak perlu dilakukan lagi karena datanya sudah dapat dianggap homogen. Namun untuk varians yang tidak sama besar perlu diadakan pengujian homogenitas melalui uji $F$.

$$
F_{\text {hitung }}=\frac{S_{1}}{S_{2}}
$$

$S_{1} \quad$ : varian terbesar

$S_{2} \quad$ : varian terkecil

Syarat homogen $F_{\text {hitung }}<F_{\text {tabel }}$ dari perhitungan di atas diperoleh dari daftar chi-kuadrat dengan $\mathrm{dk}=\mathrm{k}-2$ dan taraf signifikan $5 \%$.

3. Uji Regresi Linier Sederhana

Analisis data adalah kegiatan mengubah data hasil penelitian menjadi informasi yang dapat digunakan untuk mengambil kesimpulan dalam suatu penelitian. Sesuai jenis penelitian yang digunakan yaitu penelitian korelasional yang bertujuan untuk mengetahui hubungan antara dua variabel, maka dalam penelitian ini menggunakan rumus regresi linier sederhana sebagaimana dituliskan Arikunto, (2012;58) sebagai berikut:

$\dot{Y}=a+b X$

$$
\begin{gathered}
\mathrm{a}=\frac{\sum \mathrm{Y}-\mathrm{b} \cdot\left(\sum \mathrm{X}\right)}{\mathrm{N}} \\
\mathrm{b}=\frac{\mathrm{N} \cdot \sum \mathrm{XY}-\left(\sum \mathrm{X}\right)\left(\sum \mathrm{Y}\right)}{\sum \mathrm{X}^{2}-\left(\sum \mathrm{X}\right)^{2}}
\end{gathered}
$$

Keterangan:

$A=$ Intersep

$\mathrm{b}=$ Koofesien Regresi

$\mathrm{N}$ = Banyaknya data

$\mathrm{X}=$ Variabel Bebas ( bahan baku genteng.)

$\mathrm{Y}=$ Variabel Terikat (pendapatan pengrajin genteng) 


\section{HASIL DAN PEMBAHASAN}

\section{Hasil}

1. Uji Normalitas

Uji distribusi normal adalah uji untuk mengukur apakah data tersebut memiliki distribusi normal sehingga dapat dipakai dalam statistik parametrik. Uji normalitas bertujuan untuk mengetahui apakah suatu variabel normal atau tidak. Dalam melakukan uji normalitas data dapat menggunakan pendekatan Kolmogorov Smirnov. Kriteria pengambilan keputusan dengan pendekatan Kolmogorov-Smirnov adalah jika nilai Sig atau signifikan < 0,05 distribusi data adalah tidak normal dan jika nilai Sig atau signifikan > 0,05 distribusi data adalah normal.

2. Uji Homogenitas

Uji homogenitas data digunakan untuk menguji apakah kedua data tersebut homogen, jika kedua data varians sama besarnya, maka uji homogenitas tidak perlu dilakukan lagi karena datanya sudah dapat dianggap homogen. Berdasarkan hasil perhitungan dapat diketahui data yang homogen, hal ini ditunjukan oleh nilai signifikan 0,080>0,05.

3. Uji Linearitas

Uji statistik linear sederhana digunakan untuk menguji ada atau tidaknya pengaruh variabel melalui regresinya. Dimana regresi linear sederhana yaitu regresi dimana variabel terikatnya $(Y)$ dipengaruhi dari satu variabel bebas $(X)$. Pada uji inear sederhana ini akan menguji pengaruh anatara variabel $X$ (bahan baku) terhadap variabel $Y$ (Pendapatan pengrajin genteng masyarakat desa Gedung Rejo BK IX). Berdasarkan hasil persamaan tersebut, maka dapat dijelaskan sebagai berikut:

a. Dalam kasus ini nilainya sebesar 47,584, angka ini merupakan angka konstan yang mempunyai arti jika tidak bahan baku $(\mathrm{X})$ maka nilai konstanta pendapaatan pengrajin genteng (di desa Gedung Rejo BK IX sebesar 47,584 .

b. Koefisien regresi $X=0,525$ artinya setiap penambahan $1 \%$ tingkat bahan baku $(X)$ maka pendapatan pengrajin genteng $(Y)$ didesa Gedung Rejo BK IX akan meningkat sebesar 0,525. 


\title{
Pengaruh Ketersediaan Bahan Baku Terhadap Pendapatan Pengrajin Genteng Di Desa Gedung Rejo Bk Ix Belitang Oku Timur
}

\begin{abstract}
Berdasarkan perhitungan, nilai $\mathrm{R}$ Square $=0,314$ dengan besaran koefisien determinasi $0,314 \times 100 \%=31,4 \%$, artinya bahwa besarnya pengaruh bahan baku terhadap pendapatan pengrajin genteng didesa Gedung Rejo BK IX sebesar $31.4 \%$ sedangkan sisanya sebesar $68,6 \%$ dipengaruhi oleh faktor lain yang tidak ikut diteliti.
\end{abstract}

4. Uji t

Berdasarkan hasil perhitungan, diketahui nilai $t_{\text {hitung }}$ sebesar $3,581>t_{\text {tabel }}$ sebesar 1,70113 karena, $t_{\text {hitung }}$ lebih besar dibandingkan $t_{\text {tabel }}$ maka dapat disimpulkan bahwa HO ditolak dan Ha diterima, yang berarti bahwa ada pengaruh ketersediaan bahan baku $(X)$ terhadap pendapatan pengrajin genteng (Y) di desa Gedung Rejo BK IX.

\section{Pembahasan}

Penelitian ini terdapat satu variabel bebas yaitu ketersediaan bahan baku $(X)$ dan satu variabel terikat pendapatan pengrajin genteng desa Gedung Rejo BK IX (Y) 49 Oleh karena itu, data hasil penelitian disajikan dalam dua kelompok yaitu dat; ketersediaan bahan baku dan satu variabel terikat pendapatan pengrajin genteng desa Gedung Rejo BK IX.

Berdasarkan penelitian yang dilakukan diketahui bahwa perolehan skor angket bahan baku paling banyak adalah dalam kategori sedang. Hal tersebut dibuktikan bahwa perolehan skor angket bahan baku, sebanyak 2 pengrajin genteng $(6,67 \%)$, kategori tinggi, sebayak 25 pengrajin genteng $(83,33 \%)$ dan kategori sedang dan sebanyak 3 pengrajin genteng (10,00\%) katagori rendah. Data tersebut menunjukkan bahwa bahan baku memiliki pengaruh sedang terhadap pengrajin genteng di desa Gedung Rejo BK IX.

Berdasarkan penelitian yang dilakukan diketahui bahwa diketahui bahwa perolehan skor angket pendapatan pengrajin genteng desa Gedung Rejo BK IX paling banyak adalah dalam kategori sedang. Hal tersebut dibuktikan bahwa perolehan skor angket pendapatan pengrajin genteng, sebanyak 3 pengrajin genteng $(10,00 \%)$, kategori tinggi, sebayak 21 pendapatan pengrajin genteng $(70,00 \%)$ dan kategori sedang dan sebanyak 6 pengrajin genteng $(20,00 \%)$ katagori rendah. Data 
tersebut menunjukkan bahwa pendapatan pengrajin genteng di desa Gedung Rejo BK IX yang dipengaruhi bahan baku memiliki katagori sedang.

Hasil perhitungan regresi linear berganda tersebut dapat diketahui persamaan $\mathrm{Y}=47,584+0,525 \mathrm{X}$, dari persamaan tersebut, maka dapat dijelaskan bahwa dalam kasus ini nilainya a sebesar 47,584, angka ini merupakan angka konstan yang mempunyai arti jika tidak bahan baku $(\mathrm{X})$ maka nilai konstanta pendapaatan pengrajin genteng di desa Gedung Rejo BK IX sebesar 47,584. Sedangkan b memiliki nilai 0,525 yang memiliki arti setiap penambahan $1 \%$ tingkat bahan baku $(X)$ maka pendapatan pengrajin genteng $(\mathrm{Y})$ didesa Gedung Rejo BK IX akan meningkat sebesar 0,525.

Berdasarkan tabel di atas, nilai $\mathrm{R}$ Square $=0,314$ dengan besaran koefisien determinasi $0,314 \times 100 \%=31,4 \%$, artinya bahwa besarnya pengaruh bahan baku terhadap pendapatan pengrajin genteng didesa Gedung Rejo BK IX sebesar 31,4\% sedangkan sisanya sebesar 68,6 dipengaruhi oleh faktor lain yang tidak ikut diteliti.

Berdasarkan output di atas diketahui nilai $t_{\text {hitung }}$ sebesar $3,581>t_{\text {tabel }}$ sebesar 1,70113 karena, $t_{\text {hitung }}$ lebih besar dibandingkan $t_{\text {tabel }}$ maka dapat disimpulkan bahwa $\mathrm{HO}$ ditolak dan Ha diterima, yang berarti bahwa ada pengaruh ketersediaan bahan baku $(\mathrm{X})$ terhadap pendapatan pengrajin genteng $(\mathrm{Y})$ di desa Gedung Rejo BK IX.

\section{SIMPULAN}

Berdasarkan hasil penelitian yang telah dilaksanakan, peneliti dapat memberikan berbagai saran-saran kepada pengrajin genteng yang ada didesa Gedung Rejo BK IX,sebagai berikut:

1. Bagi Pengrajin

a. Dalam melakukan kegiatan produksi sebaiknya lebih memperhatikan ketersediaan bahan baku yang akan digunakan dalam melakukan produksi. Melihat pentingnya bahan baku merupakan bahan pokok yang akan digunakan dalam melakukan kegiatan produksi.

b. Para pengrajin genteng di desa Gedung Rejo BK IX harus bisa menekan penggunaan bahan baku yang digunakan dalam memproduksi genteng sehingga pada akhirnya dapat memperoleh pendapatan yang maksimal, 


\section{Pengaruh Ketersediaan Bahan Baku Terhadap Pendapatan Pengrajin Genteng Di Desa Gedung Rejo Bk Ix Belitang Oku Timur}

sesuai yang diharapkan oleh para pengrajin genteng di desa Gedung Rejo

BK IX.

2. Bagi Pemerintah

Pemerintah OKU Timur Khusunya Kecamatan Belitang diharapkan memperhatikan keterbatasan pengrajin untuk mendapatkan bahan baku yang berkualitas, jadi diharapkan pemerintah bisa memberikan bantuan modal baik dalam bentuk UMKM maupun KUR.

3. Penelitian Selanjutnya

a. Peneliti selanjutnya diharapkan dalam melakukan peneliti yang berjudul sama atau menyerupai sebaiknya lebih memperhatikan teori ekonomi baik ekonomi mikro, ekonomi makro maupun ekonomi pembangunan.

b. Dalam melakukan penelitian yang sifatnya mencakup masyarakat banyak sebaiknya lakukanlah pengambilan data dengan benar supaya tidak terjadi kendala.

c. Dalam penelitian harus difokuskan terhadap identifikasi masalah yang muncul didalam penelitian, seperti ketersediaan bahan baku, pendapatan pengrajin, dan pengaruh yang muncul dari ketersediaan bahan baku terhadap pendapatan pengrajin genteng desa Gedung Rejo BK IX..

\section{UCAPAN TERIMAKASIH}

Semua pihak yang telah berpatisipasi dalam membantu menyelesaikan artikel ini. dan juga pengalaman. Terimakasih juga kepada tim Journal UTILITY STKIP Nurul Huda.

\section{REFERENSI}

Arikunto. S, 2013. Prosedur Penelitian : Suatu Pendekatan Praktik, Jakarta. Asdi Mahasetya

Arininour Maliha, Skripsi 2018. Pengaruh Modal, Tenaga Kerja, dan Bahan Baku Terhadap Tingkat Pendapatan Industri Kue Dalam Perspektif Ekonomi Islam

Assauri Sofjan, 2015. Menejemen Pemasaran, Jakarta. PT Raja Grafindo Persada 
Evy Sugiarti, 2018, dengan judul "Pengaruh Modal,Bahan Baku, dan Tenaga Kerja, terhadap Pendapatan Pengrajin Genteng (Studi Kasus Masyarakat Sumberingin Kulon, Kecamatan Ngunut, Kabupaten Tulungagung)"

Hanggana Sari, 2014. Prinsip Dasar-Dasar Akuntansi Biaya, Mediatama Surakarta

Mulyadi, 2012, Akuntansi Biaya, Edisi Ke-5. Penerbit Sekolah Tinggi IImu Menejemen YKPN

Nata, 2013. Jurnal. Meneliti tentang "Pengaruh Tenaga Kerja, Modal, dan Bahan Baku Pada Pendapatan Pengrajin Perak di desa Kamasan Klungkung kabupaten Klungkung".

Prathama Rahardia, Mandala Manurung, 2010. Teori Ekonomi Mikro (Jakarta: Lembang Penerbit FE UI

Santa Permata, 2019. Pengaruh Upah, Bahan Baku, dan Lama Usaha Terhadap Produktivitas Tenaga Kerja Industri Tahu di Kecamatan Manisrenggo

Sudarsono, 2011. Ekonomi Sumber Daya Manusia. Jakarta

Suherman Rosyidi, 2012 Pengantar Teori Ekonomi : Pendekatan Kepada Teori Ekonomi Mikro dan Makro. Jakarta : PT: Raja Grafindo

Sugiyono, 2013. Metode Penelitian Kombinasi (Mixed Method). Bandung : Alfabeta

Suma M. Amin, 2015. Pengantar Ekonomi Syariah. Bandung: cv pustaka Setia.

Yulianti, E. (2015). Pengaruh Pelatihan Terhadap Kinerja Karyawan Grand Fatma Hotel di Tenggarong Kutai Kartanegara. E-Jurnal Administrasi Bisnis, 3(4), 900-910. 